\title{
Genome-wide association analysis with selective genotyping identifies candidate loci for adult height at 8q21.13 and 15q22.33-q23 in Mongolians
}

\author{
Tetsuaki Kimura • Terukazu Kobayashi · Batmunkh Munkhbat · Ganjuur Oyungerel · \\ Tsolmon Bilegtsaikhan • Damdinsuren Anar · Jamiyansuren Jambaldorj • Sodnom Munkhsaikhan • \\ Namid Munkhtuvshin · Hideki Hayashi · Akira Oka • Ituro Inoue · Hidetoshi Inoko
}

Received: 6 February 2008 / Accepted: 12 May 2008 / Published online: 20 May 2008

(C) The Author(s) 2008

\begin{abstract}
We performed a genome-wide association study with 23,465 microsatellite markers to identify genes related to adult height. Selective genotyping was applied to extremely tall and extremely short individuals from the Khalkh-Mongolian population. Two loci, 8q21.13 and $15 \mathrm{q} 22.33$, which showed the strongest association with microsatellites were subjected to further analyses of SNPs in 782 tall and 773 short individuals. The most significant association was observed with SNP rs2220456 at 8q21.13 $(P=0.000016)$. In the LD block at $15 \mathrm{q} 22.32$, SNP rs8038652 located in intron 1 of $I Q C H$ was strongly associated $(P=0.0003)$, especially the AA genotype of the SNP under a recessive model was strongly associated with adult height $(P=0.000046)$.
\end{abstract}

\section{Introduction}

Adult height is an explicit quantitative phenotype and stable once a person has grown and is easily measured. Adult height is largely controlled by genetic factors, with

T. Kimura - T. Kobayashi - B. Munkhbat $\cdot$ H. Hayashi · A. Oka I. Inoue $\cdot$ H. Inoko $(\bowtie)$

Department of Molecular Life Science and Molecular Medicine, Tokai University School of Medicine, 143 Shimokasuya, Isehara, Kanagawa 259-1193, Japan

e-mail: hinoko@is.icc.u-tokai.ac.jp

T. Kimura

e-mail: tekimura@is.icc.u-tokai.ac.jp

B. Munkhbat · G. Oyungerel · T. Bilegtsaikhan · D. Anar · J. Jambaldorj · S. Munkhsaikhan · N. Munkhtuvshin Central Scientific Research Laboratory,

National Institute of Medicine, Ulaanbaatar, Mongolia heritability ranging from 75 to $90 \%$ in various populations (Carmichael and McGue 1995; Silventoinen et al. 2003).

Adult height usually follows normal distribution in a given population and sex, the phenotype representing a typical polygenic model of a human quantitative trait influenced by multiple genes each with small effects. Numerous linkage studies have attempted to identify loci underlying adult height variation. Thompson et al. first reported a locus for adult height on chromosome 20 in Pima Indians (Thompson et al. 1995). Several other groups reported evidence of linkage with adult height in Europeans (Beck et al. 2003; Dempfle et al. 2006; Deng et al. 2002; Ellis et al. 2007; Geller et al. 2003; Hirschhorn et al. 2001; Liu et al. 2006; Mukhopadhyay et al. 2003; Mukhopadhyay and Weeks 2003; Perola et al. 2001; Perola et al. 2007; Sammalisto et al. 2005; Willemsen et al. 2004; Wiltshire et al. 2002; Xu et al. 2002). Wu et al. (2003) found evidence of linkage in four ethnic groups; White, Black, Mexican American, and Asian. Most recently, Visscher reported a large-scale linkage study with 11,214 sibling pairs showing that additive genetic variance is spread across multiple chromosomes, with no evidence of large between-chromosome epistatic effects (Visscher et al. 2007). While multiple evidence of linkage of adult height has been identified in several populations in these studies, common loci are not evident.

Since linkage study has limited power to detect genes of modest effect, especially where there is genetic heterogeneity, we applied association study with a sufficient number of subjects to identify genes with a small impact on the phenotype (Risch and Merikangas 1996). Recently, some groups reported genes associated with adult height variation using data from genome-wide association study (Gudbjartsson et al. 2008; Lettre et al. 2008; Sanna et al. 2008; Weedon et al. 2007, 2008). In the present study, we report results of a genome-wide association study of adult height with 1,555 
individuals from the Khalkh population of Mongolia using 23,465 microsatellite markers. The Khalkh population has a relatively close genetic affinity to populations of the northern part of East Asia showing a relatively homogeneous genetic background, which provides an advantage to study complex phenotype (Katoh et al. 2002, 2005; Nakajima et al. 2004). We applied a selective genotyping strategy in which individuals with trait values deviating from the population mean were preferentially recruited to identify genetic variations underlying quantitative traits with improved power (Arking et al. 2006; Lander and Botstein 1989).

\section{Material and methods}

Study subject selection

Adult height for both male and female shows normal distribution with average height and standard deviation being $164.76 \pm 5.74 \mathrm{~cm}$ for male and $153.76 \pm 5.04 \mathrm{~cm}$ for female according to epidemiological and anthropometric surveys on adult height among Khalkh-Mongolians (Otgon et al. 2002; personal communication L. Namsrainaidan). A total of 1,555 unrelated individuals of Khalkh-Mongolian origin from the region of Ulaanbaatar, Mongolia participated in the current study. The selection of individuals from the general population was $>95$ th percentile for the tall group corresponding to $>173.9 \mathrm{~cm}$ and $<5$ th percentile for the short group corresponding to $<155.6 \mathrm{~cm}$ for male and 161.8 and $145.7 \mathrm{~cm}$, respectively, for female. The subjects in the short group were over 18 years of age and those in the tall group were over 15 years of age at the time of examination. Individuals with medical conditions affecting adult height, such as dwarfism, gigantism, and acromegaly were excluded. The study was approved by the Institutional Review Board of Tokai University and the Medical Research Ethics Committee of the National Institute of Medicine and the Ethics Committee, Ministry of Health, Mongolia. The participants gave written, informed consent.

DNA pool construction and microsatellite genotyping

The pooled DNA method for microsatellite typing was performed according to the protocol of Collins et al. (2000) with a slight modification (Oka et al. 2003). DNA was extracted using QIAamp DNA blood kit (QIAGEN) under the standardized protocol to prevent variation of DNA quality. The DNA concentration was precisely measured using the PicoGreen fluorescence assay (Molecular Probes) as previously described (Tamiya et al. 2005; Kawashima et al. 2006). For the first round screening, four DNA pools were prepared. The first set for association study was DNA pools of 125 male-tall, 125 male-short, 125 female-tall, and 125 female-short samples, respectively. A second set was also grouped from another 125 male- and female-tall samples and 125 male- and female-short samples, respectively. In the first round screening, 23,465 microsatellite markers were used. Among them, showing statistical significance of $P<0.05$ were subjected to the second round screening.

All microsatellite markers and methods for microsatellite genotyping used in this study are described by Tamiya et al. (2005). PCR on pooled DNAs was performed in a $20-\mu \mathrm{l}$ reaction mixture containing $48 \mathrm{ng}$ of pooled DNA, $0.5 \mathrm{U}$ of AmpliTaq DNA polymerase, $1 \times$ reaction buffer with $1.5 \mathrm{mM} \mathrm{MgCl} 2$ provided by the manufacturer (Applied Biosystems), $5 \mu \mathrm{M}$ of each primer, and $0.25 \mathrm{mM}$ of each deoxyriobonucleotide triphosphate (dNTP) in 96-well plates. The PCR amplification was performed on the GeneAmp PCR System 9700 (Applied Biosystems) with the following conditions: $96^{\circ} \mathrm{C}$ for $5 \mathrm{~min}$ (hot start), $57^{\circ} \mathrm{C}$ for $1 \mathrm{~min}$, and $72^{\circ} \mathrm{C}$ for $1 \mathrm{~min}$ followed by 40 cycles of $96^{\circ} \mathrm{C}$ for $45 \mathrm{~s}, 57^{\circ} \mathrm{C}$ for $45 \mathrm{~s}$ and $72^{\circ} \mathrm{C}$ for $1 \mathrm{~min}$. For the microsatellite genotyping of individual samples, PCR was performed in a $20 \mu \mathrm{l}$ reaction containing $1 \mathrm{ng}$ of genomic DNA. The amplification condition was the same as described above. The pooled and individual microsatellite genotyping procedures after PCR amplification were carried out according to standard protocols using ABI3730 DNA analyzer (Applied Biosystems). Peak positions and heights were automatically extracted by the PickPeak and MultiPeaks programs.

\section{SNP genotyping}

The SNPs in candidate regions were selected from the SNP database of Applied Biosystems (http://www2.appliedbiosystems.com/) using SNPbrowser software 3.5 (Applied Biosystems). The SNPs were genotyped by TaqMan assays. The TaqMan assays were carried out using the standard protocols for the ABI PRISM 7900HT Sequence Detection System using a 384-well block module and automation accessory (Applied Biosystems).

\section{Statistical analysis}

In pooled DNA typing, adult height associations with microsatellites were assessed by Fisher's exact test, with the use of $2 \times 2$ contingency tables for each allele. Allele frequencies in pooled DNA typing were estimated from the height of peaks: each allele frequency was determined by dividing the height of each allele by the summed height of all alleles. In individual genotyping, significance was evaluated by Fisher's exact test, with the use of $2 \times 2$ contingency tables for each allele.

For SNPs genotyping, adult height associations were assessed using chi-square test (Haploview 4.0 software [http:// www.broad.mit.edu/mpg/haploview/]). Since multi-step 
analysis was used, the nominal $P$ values were corrected with $1,000,000$ iterated permutations for all 82 SNPs. Significance level was set at .05 throughout the study.

To assess the extent of pair-wise linkage disequilibrium between SNPs, standard definition of $D^{\prime}$ and $r^{2}$ were calculated using Haploview software. $D^{\prime}$ and $r^{2}$ were calculated only for polymorphisms with minor-allele frequency (MAF) $>5 \%$. LD blocks were then defined with pair-wise LD with $D^{\prime}>0.9$.

\section{Results and discussion}

Genome-wide association study

We performed a genome-wide association study with 23,465 microsatellite markers for detection of loci control- ling adult height using the selective genotyping method. To reduce cost and technical burden of genome-wide genotyping, the pooled DNA method was applied, as previously described (Collins et al. 2000, Tamiya et al. 2005). Association results with the pooled DNA method and following re-genotyping of individual DNAs using the same set of 1,000 screened individuals, 23 markers showed significant differences by Fisher's exact test (Table 1). These markers were subjected to correction of multiple tests with the number of alleles, and nine microsatellites remained significant.

Visscher et al. reported that at least six chromosomes (3, $4,8,15,17$, and 18) were responsible for height variation in the European population (Visscher et al. 2007). We also detected significant association in those chromosomes, except chromosome 18. In addition, five regions overlapped at least partially with loci previously reported by

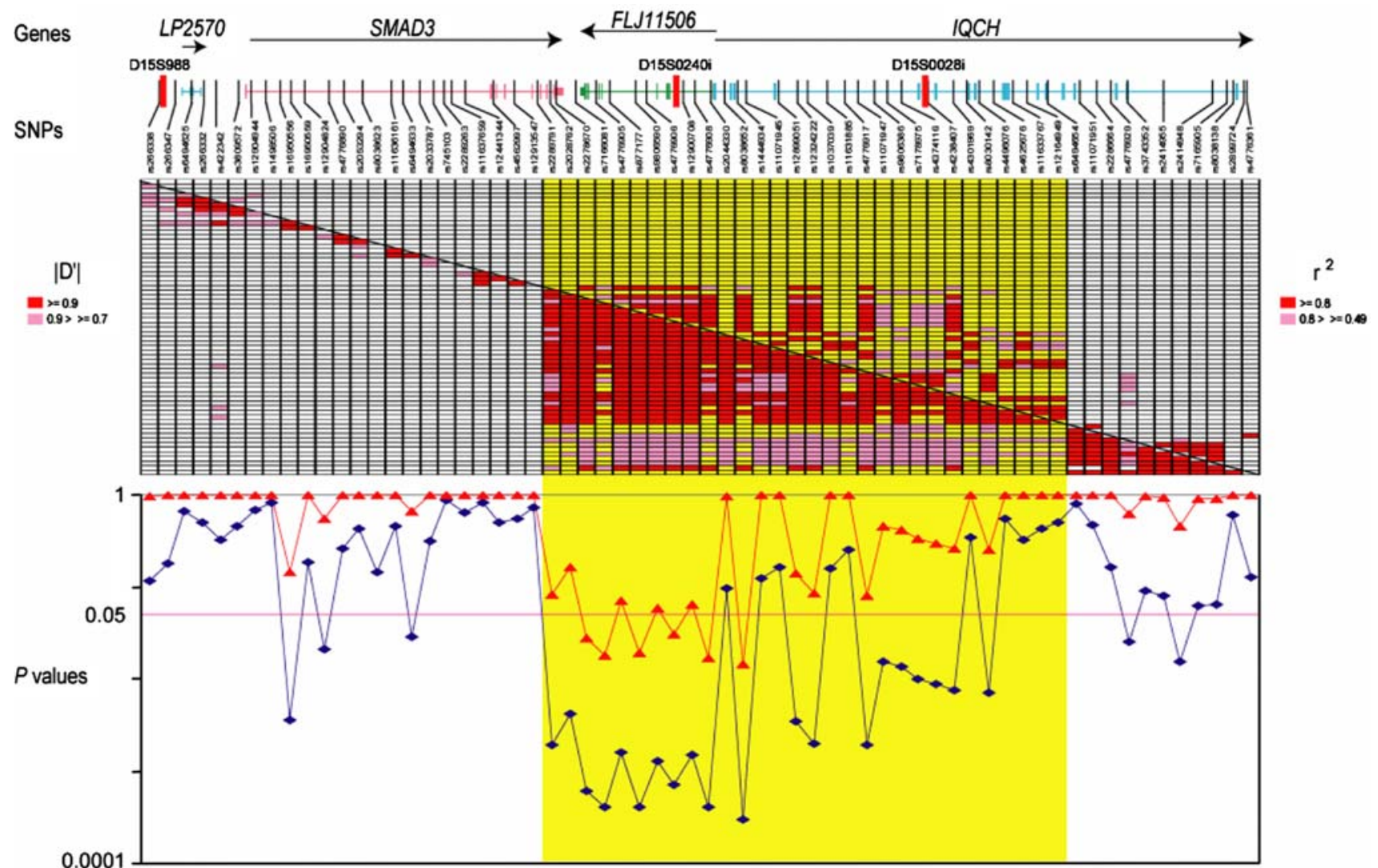

$100 \mathrm{~kb}$

Fig. 1 SNP allelic association within 15q22.33-q23. SNP association analysis. The blue line shows $P$ values calculated by chi square test. The red line shows $P$ values generated after 1,000,000 iterated permutations. Yellow background indicates the $188 \mathrm{~kb}$ LDB. In the Mongolian population, we investigated the $188 \mathrm{~kb}$ LD block constructed by these significant markers spanning from intron 6 of SMAD3 (rs2289791) to intron 10 of IQCH (rs12164949). The LD block contained the MH2 domain and the 3' UTR of SMAD3, the entire coding sequence of $F L J 11506$, and the IQ domain of $I Q C H$. SNP rs8038652 located in intron 1 of $I Q C H$ was most strongly associated $(P=0.0003$, $P c=0.015)$ with adult height. SNP rs227860 located in the $3^{\prime}$ UTR of SMAD3 also was associated $(P=0.0006, P c=0.028)$. SNP rs7166081 $(P=0.0004, P c=0.018)$ was in an intergenic region between $S M A D 3$ and FLJ11506. Three remaining SNPs, rs4776908 $(P=0.0004$, $P c=0.017), \quad$ rs877177 $(P=0.0004, P c=0.020)$, and $\mathrm{rs} 4776906$ $(P=0.0007, P c=0.030)$ located in intron 1,5 , and 5 of $F L J 11506$, respectively, were also associated 
Table 1 Twenty-three positive microsatelllite markers from individual genotyping

\begin{tabular}{|c|c|c|c|c|c|c|c|c|c|}
\hline \multirow[t]{2}{*}{ No. } & \multirow[t]{2}{*}{ Markers } & \multirow[t]{2}{*}{ Locus } & \multirow{2}{*}{$\begin{array}{l}\text { Number } \\
\text { of allele }\end{array}$} & \multicolumn{2}{|c|}{ Allele frequencies } & \multicolumn{2}{|c|}{ Fisher's exact $P$ value } & \multirow[t]{2}{*}{ Odds ratio } & \multirow[t]{2}{*}{$95 \% \mathrm{CI}$} \\
\hline & & & & Tall & Short & Exact $2 \times 2$ & Corrected* & & \\
\hline 1. & D1S2660 & 1q36.32 & 12 & 0.093 & 0.061 & 0.0090 & 0.11 & 1.58 & $1.13-2.21$ \\
\hline 2. & D2S0257i & $2 q 33.1$ & 16 & 0.092 & 0.132 & 0.0050 & 0.080 & 0.67 & $0.50-0.88$ \\
\hline 3. & D3S0229i & $3 \mathrm{p} 24.1$ & 16 & 0.122 & 0.169 & 0.0040 & 0.064 & 0.69 & $0.54-0.89$ \\
\hline 4. & D3S0085i & $3 q 33.2$ & 20 & 0.031 & 0.056 & 0.0080 & 0.16 & 0.54 & $0.35-0.85$ \\
\hline 5. & HUMUT880B & $4 q 13.2$ & 30 & 0.123 & 0.074 & 0.00029 & 0.0088 & 0.43 & $0.26-0.71$ \\
\hline 6. & D4S1126i & $4 q 31.3$ & 27 & 0.017 & 0.042 & 0.0010 & 0.027 & 0.19 & $0.07-0.57$ \\
\hline 7. & D5S1328i & $5 q 21.3$ & 10 & 0.045 & 0.081 & 0.0010 & 0.010 & 0.54 & $0.37-0.78$ \\
\hline 8. & D5S0703i & $5 q 31.2$ & 9 & 0.227 & 0.185 & 0.023 & 0.21 & 1.29 & $1.04-1.61$ \\
\hline 9. & HUMUT5011 & $6 \mathrm{p} 12.3$ & 19 & 0.075 & 0.110 & 0.0090 & 0.17 & 0.51 & $0.33-0.78$ \\
\hline 10. & D6S1146i & $6 \mathrm{p} 22.3$ & 13 & 0.000 & 0.006 & 0.031 & 0.40 & - & - \\
\hline 11. & HUMUT5779 & $6 \mathrm{q} 25.1$ & 11 & 0.287 & 0.217 & 0.00031 & 0.0034 & 1.45 & $1.19-1.78$ \\
\hline 12. & D7S0070i & $7 \mathrm{p} 21.1$ & 10 & 0.426 & 0.351 & 0.00067 & 0.0067 & 1.37 & $1.15-1.65$ \\
\hline 13. & D7S0046i & $7 q 11.22$ & 11 & 0.105 & 0.165 & 0.000083 & 0.00091 & 0.59 & $0.46-0.77$ \\
\hline 14. & D8S0913i & $8 \mathrm{q} 21.3$ & 13 & 0.026 & 0.010 & 0.011 & 0.14 & 2.64 & $1.27-5.50$ \\
\hline 15. & D8S0285i & $8 \mathrm{q} 21.13$ & 6 & 0.208 & 0.150 & 0.000036 & 0.00022 & 0.68 & $0.57-0.82$ \\
\hline 16. & D9S0673i & 9 p13.3 & 14 & 0.109 & 0.076 & 0.011 & 0.15 & 1.50 & $1.10-2.04$ \\
\hline 17. & D11S1765 & $11 \mathrm{q} 12.2$ & 9 & 0.033 & 0.017 & 0.031 & 0.28 & 1.97 & $1.09-3.56$ \\
\hline 18. & D12S0914i & $12 q 12$ & 8 & 0.179 & 0.144 & 0.038 & 0.30 & 1.30 & $1.02-1.65$ \\
\hline 19. & D14S0504i & $14 q 32.12$ & 27 & 0.071 & 0.038 & 0.0020 & 0.054 & 1.93 & $1.29-2.89$ \\
\hline 20. & D15S988 & $15 q 22.33$ & 15 & 0.100 & 0.062 & 0.0020 & 0.030 & 1.68 & $1.21-2.33$ \\
\hline 21. & D17S0234i & $17 \mathrm{p} 13.2$ & 14 & 0.163 & 0.130 & 0.036 & 0.50 & 1.31 & $1.02-1.68$ \\
\hline 22. & HUMUT6385 & $19 \mathrm{q} 13.2$ & 9 & 0.071 & 0.116 & 0.00053 & 0.0048 & 0.58 & $0.43-0.79$ \\
\hline 23. & D21S0059i & $21 q 21.1$ & 16 & 0.158 & 0.124 & 0.034 & 0.54 & 1.32 & $1.03-1.70$ \\
\hline
\end{tabular}

$P$ values calculated by Fisher's exact test, based on $2 \times 2$ contingency tables. The smallest $P$ value was selected.

* $P$ values were corrected by the number of alleles. The Fisher's exact test was carried out in the sex-pooled tall and short subjects $(n=500$ each). CI, confidence interval

linkage analysis, 5q31 (Wu et al. 2003), 6q25 (Hirschhorn et al. 2001; Xu et al. 2002), 8q21.3 (Perola et al. 2007), $8 \mathrm{q} 21.13$ (Willemsen et al. 2004), and 21q21.1 (Hirschhorn et al. 2001), respectively. We also detected six strongly associated regions, 4q13.2, 4q $31.3,5 \mathrm{q} 21.3,7 \mathrm{p} 21.1$, $7 \mathrm{q} 11.22$, and $19 \mathrm{q} 13.2$, which have not been reported before. The inconsistent results of these studies may be due to population specificities and/or differences of technique.

Fine mapping by SNP

Among the nine most associated markers, we selected two: D8S0285i and D15S988. D8S0285i was the most strongly associated microsatellite, located at 8q21.13, and D15S988 was flanked by a candidate gene, SMAD3, located at 15q22.33. 82 SNPs were surveyed and genotyped in a total of 1,555 samples (1,000 screened samples and additional 555 samples).

Ten SNPs at 8q21.13 showed nominal significance, among which SNP rs2220456 was the most strongly associated with height, showing empirical significance
$(P=0.000016, \quad P c=0.0008)$. These SNP associations might be reflected the reported evidence of linkage (Perola et al. 2007: Willemsen et al. 2004). Since an approximately $300 \mathrm{~kb}$ region in the vicinity of SNP rs2220456 and D8S0285i at $8 \mathrm{q} 21.3$ had no coding sequence according to NCBI build 36.2, we shifted our target to the locus at 15q22.33-q23. To cover a gene-containing region, we selected two additional microsatellites, D15SO240i and D15S0028i, and 64 SNPs at 15q22.33-q23 (Fig. 1). Among these, allele 230 of $D 15 S 0240 i$ and six SNPs retained empirical significance $(P C<0.05)$ as depicted in Figure1. SNP rs8038652, the most strongly associated SNP, is located in intron 1 of $I Q C H$. The six SNPs maintained a strong LD index with each other $\left(D^{\prime}>0.9\right.$ and $\left.r^{2}=0.8\right)$. Additionally, SNP rs8038652 and allele 230 of D15SO240i were in strong $\operatorname{LD}\left(D^{\prime}=0.99\right.$ and $\left.r^{2}=0.77\right)$.

Based on the SNP association results, SNP rs8038652 was further analyzed under different genetic models. Association analysis under a recessive model for SNP rs8038652 showed the lowest $P$ value $(P=0.000046)$ with the AA genotype, indicating that the AA genotype of 
rs8038652 has an adverse effect on adult height in Mongolians (odds ratio $=0.59$, confidence interval, 0.46-0.76). Additionally, a deviation from $\operatorname{HWE}(P=0.04)$ was observed in the tall height group with SNP rs8038652.

In conclusion, we have identified two candidate loci for adult height at 8q21.13 and 15q22.33-q23 in Mongolians. Although the causative polymorphisms were not determined in this study, we were able to locate genetic association with adult height to two regions. 15q22.33-q23 contains only three genes, so functional analyses should help to elucidate the causative polymorphisms. Analysis of the remaining seven highly associated microsatellite markers should lead to identification of new causative genes underlying adult height variation.

Acknowledgments This work was supported in part by the Research and Study Program of Tokai University Educational System General Research Organization, by the Center of Excellence 21st century program, and by a Grant-in-Aid for Scientific Research on Priority Areas "Applied Genomics" from the Ministry of Education, Culture, Sports, Science and Technology of Japan.

Open Access This article is distributed under the terms of the Creative Commons Attribution Noncommercial License which permits any noncommercial use, distribution, and reproduction in any medium, provided the original author(s) and source are credited.

\section{References}

Arking DE, Pfeufer A, Post W, Kao WH, Newton-Cheh C, Ikeda M, West K, Kashuk C, Akyol M, Perz S, Jalilzadeh S, Illig T, Gieger C, Guo CY, Larson MG, Wichmann HE, Marbán E, O'Donnell CJ, Hirschhorn JN, Kääb S, Spooner PM, Meitinger T, Chakravarti A (2006) A common genetic variant in the NOS1 regulator NOS1AP modulates cardiac repolarization. Nat Genet 38:644651

Beck SR, Brown WM, Williams AH, Pierce J, Rich SS, Langefeld CD (2003) Age-stratified QTL genome scan analyses for anthropometric measures. BMC Genet 4(Suppl 1):S31

Carmichael CM, McGue M (1995) A cross-sectional examination of height, weight, and body mass index in adult twins. J Gerontol A Biol Sci Med Sci 50:B237-B244

Cogan JD, Phillips JA 3rd, Sakati N, Frisch H, Schober E, Milner RD (1993) Heterogeneous growth hormone $(\mathrm{GH})$ gene mutations in familial GH deficiency. J Clin Endocrinol Metab 76:1224-1228

Collins HE, Li H, Inda SE, Anderson J, Laiho K, Tuomilehto J, Seldin MF (2000) A simple and accurate method for determination of microsatellite total allele content differences between DNA pools. Hum Genet 106:218-226

Dempfle A, Wudy SA, Saar K, Hagemann S, Friedel S, Scherag A, Berthold LD, Alzen G, Gortner L, Blum WF, Hinney A, Nürnberg P, Schäfer H, Hebebrand J (2006) Evidence for involvement of the vitamin D receptor gene in idiopathic short stature via a genome-wide linkage study and subsequent association studies. Hum Mol Genet 15:2772-2783

Deng HW, Xu FH, Liu YZ, Shen H, Deng H, Huang QY, Liu YJ, Conway T, Li JL, Davies KM, Recker RR (2002) A whole-genome linkage scan suggests several genomic regions potentially containing QTLs underlying the variation of stature. Am J Med Genet 113:29-39
Ellis JA, Scurrah KJ, Duncan AE, Lamantia A, Byrnes GB, Harrap SB (2007) Comprehensive multi-stage linkage analyses identify a locus for adult height on chromosome $3 p$ in a healthy Caucasian population. Hum Genet 121:213-222

Geller F, Dempfle A, Görg T (2003) Framingham Heart Study. Genome scan for body mass index and height in the Framingham Heart Study. BMC Genet 4(Suppl 1):S91

Gudbjartsson DF, Walters GB, Thorleifsson G, Stefansson H, Halldorsson BV, Zusmanovich P, Sulem P, Thorlacius S, Gylfason A, Steinberg S, Helgadottir A, Ingason A, Steinthorsdottir V, Olafsdottir EJ, Olafsdottir GH, Jonsson T, Borch-Johnsen K, Hansen T, Andersen G, Jorgensen T, Pedersen O, Aben KK, Witjes JA, Swinkels DW, den Heijer M, Franke B, Verbeek AL, Becker DM, Yanek LR, Becker LC, Tryggvadottir L, Rafnar T, Gulcher J, Kiemeney LA, Kong A, Thorsteinsdottir U, Stefansson K (2008) Many sequence variants affecting diversity of adult human height. Nat Genet 40:609-615

Hirschhorn JN, Lindgren CM, Daly MJ, Kirby A, Schaffner SF, Burtt NP, Altshuler D, Parker A, Rioux JD, Platko J, Gaudet D, Hudson TJ, Groop LC, Lander ES (2001) Genomewide linkage analysis of stature in multiple populations reveals several regions with evidence of linkage to adult height. Am J Hum Genet 69:106-116

Katoh T, Mano S, Ikuta T, Munkhbat B, Tounai K, Ando H, Munkhtuvshin N, Imanishi T, Inoko H, Tamiya G (2002) Genetic isolates in East Asia: a study of linkage disequilibrium in the $\mathrm{X}$ chromosome. Am J Hum Genet 71:395-400

Katoh T, Munkhbat B, Tounai K, Mano S, Ando H, Oyungerel G, Chae GT, Han H, Jia GJ, Tokunaga K, Munkhtuvshin N, Tamiya G, Inoko H (2005) Genetic features of Mongolian ethnic groups revealed by Y-chromosomal analysis. Gene 346:63-70

Kawashima M, Tamiya G, Oka A, Hohjoh H, Juji T, Ebisawa T, Honda Y, Inoko H, Tokunaga K (2006) Genomewide association analysis of human narcolepsy and a new resistance gene. Am J Hum Genet 79:252-263

Lander ES, Botstein D (1989) Mapping mendelian factors underlying quantitative traits using RFLP linkage maps. Genetics 121:185199

Lettre G, Jackson AU, Gieger C, Schumacher FR, Berndt SI, Sanna S, Eyheramendy S, Voight BF, Butler JL, Guiducci C, Illig T, Hackett R, Heid IM, Jacobs KB, Lyssenko V, Uda M; The Diabetes Genetics Initiative; FUSION; KORA; The Prostate, Lung Colorectal and Ovarian Cancer Screening Trial; The Nurses' Health Study; SardiNIA, Boehnke M, Chanock SJ, Groop LC, Hu FB, Isomaa B, Kraft P, Peltonen L, Salomaa V, Schlessinger D, Hunter DJ, Hayes RB, Abecasis GR, Wichmann HE, Mohlke KL, Hirschhorn JN (2008) Identification of ten loci associated with height highlights new biological pathways in human growth. Nat Genet. 40:584-591

Liu YZ, Xiao P, Guo YF, Xiong DH, Zhao LJ, Shen H, Liu YJ, Dvornyk V, Long JR, Deng HY, Li JL, Recker RR, Deng HW (2006) Genetic linkage of human height is confirmed to 9q22 and Xq24. Hum Genet 119:295-304

Mukhopadhyay N, Finegold DN, Larson MG, Cupples LA, Myers RH, Weeks DE (2003) A genome-wide scan for loci affecting normal adult height in the Framingham Heart Study. Hum Hered 55:191201

Mukhopadhyay N, Weeks DE (2003) Linkage analysis of adult height with parent-of-origin effects in the Framingham Heart Study. BMC Genet. 41(Suppl 1):S76

Nakajima T, Wooding S, Sakagami T, Emi M, Tokunaga K, Tamiya G, Ishigami T, Umemura S, Munkhbat B, Jin F, Guan-Jun J, Hayasaka I, Ishida T, Saitou N, Pavelka K, Lalouel JM, Jorde LB, Inoue I (2004) Natural selection and population history in the human angiotensinogen gene (AGT): 736 complete AGT sequences in chromosomes from around the world. Am J Hum Genet 74:898-916 
Oka A, Hayashi H, Tomizawa M, Okamoto K, Suyun L, Hui J, Kulski JK, Beilby J, Tamiya G, Inoko H (2003) Localization of a nonmelanoma skin cancer susceptibility region within the major histocompatibility complex by association analysis using microsatellite markers. Tissue Antigens 61:203-210

Otgon G, Lkhagva L, Sarantuya G (2002) Normal values of physiological and laboratory parameters in human. Edmon Publishing Company, Ulaanbaatar, Mongolia

Perola M, Ohman M, Hiekkalinna T, Leppävuori J, Pajukanta P, Wessman M, Koskenvuo M, Palotie A, Lange K, Kaprio J, Peltonen L (2001) Quantitative-trait-locus analysis of body-mass index and of stature, by combined analysis of genome scans of five Finnish study groups. Am J Hum Genet 69:117-123

Perola M, Sammalisto S, Hiekkalinna T, Martin NG, Visscher PM, Montgomery GW, Benyamin B, Harris JR, Boomsma D, Willemsen G, Hottenga JJ, Christensen K, Kyvik KO, Sørensen TI, Pedersen NL, Magnusson PK, Spector TD, Widen E, Silventoinen K, Kaprio J, Palotie A, Peltonen L, GenomEUtwin Project (2007) Combined genome scans for body stature in 6, 602 European twins: evidence for common Caucasian loci. PLoS Genet 8:10191028

Risch N, Merikangas K (1996) The future of genetic studies of complex human diseases. Science 273:1516-1517

Sammalisto S, Hiekkalinna T, Suviolahti E, Sood K, Metzidis A, Pajukanta P, Lilja HE, Soro-Paavonen A, Taskinen MR, Tuomi T, Almgren P, Orho-Melander M, Groop L, Peltonen L, Perola M (2005) A male-specific quantitative trait locus on 1 p21 controlling human stature. J Med Genet 42:932-939

Sanna S, Jackson AU, Nagaraja R, Willer CJ, Chen WM, Bonnycastle LL, Shen H, Timpson N, Lettre G, Usala G, Chines PS, Stringham HM, Scott LJ, Dei M, Lai S, Albai G, Crisponi L, Naitza S, Doheny KF, Pugh EW, Ben-Shlomo Y, Ebrahim S, Lawlor DA, Bergman RN, Watanabe RM, Uda M, Tuomilehto J, Coresh J, Hirschhorn JN, Shuldiner AR, Schlessinger D, Collins FS, Davey Smith G, Boerwinkle E, Cao A, Boehnke M, Abecasis GR, Mohlke KL (2008) Common variants in the GDF5-UQCC region are associated with variation in human height. Nat Genet 40:198-203

Silventoinen K, Sammalisto S, Perola M, Boomsma DI, Cornes BK, Davis C, Dunkel L, De Lange M, Harris JR, Hjelmborg JV, Luciano M, Martin NG, Mortensen J, Nisticò L, Pedersen NL, Skytthe A, Spector TD, Stazi MA, Willemsen G, Kaprio J (2003) Heritability of adult body height: a comparative study of twin cohorts in eight countries. Twin Res 6:399-408

Tamiya G, Shinya M, Imanishi T, Ikuta T, Makino S, Okamoto K, Furugaki K, Matsumoto T, Mano S, Ando S, Nozaki Y, Yukawa W, Nakashige R, Yamaguchi D, Ishibashi H, Yonekura M, Nakami Y, Takayama S, Endo T, Saruwatari T, Yagura M, Yoshikawa Y, Fujimoto K, Oka A, Chiku S, Linsen SE, Giphart MJ, Kulski JK, Fukazawa T, Hashimoto H, Kimura M, Hoshina Y, Suzuki Y, Hotta T, Mochida J, Minezaki T, Komai K, Shiozawa S, Taniguchi A, Yamanaka H, Kamatani N, Gojobori T, Bahram S,
Inoko H (2005) Whole genome association study of rheumatoid arthritis using 27039 microsatellites. Hum Mol Genet 14:23052321

Thompson DB, Ossowski V, Janssen RC, Knowler WC, Bogardus C (1995) Linkage between stature and a region on chromosome 20 and analysis of a candidate gene, bone morphogenetic protein 2 . Am J Med Genet 59:495-500

Visscher PM, Macgregor S, Benyamin B, Zhu G, Gordon S, Medland S, Hill WG, Hottenga JJ, Willemsen G, Boomsma DI, Liu YZ, Deng HW, Montgomery GW, Martin NG (2007) Genome partitioning of genetic variation for height from 11, 214 sibling pairs. Am J Hum Genet 81:1104-1110

Weedon MN, Lango H, Lindgren CM, Wallace C, Evans DM, Mangino M, Freathy RM, Perry JR, Stevens S, Hall AS, Samani NJ, Shields B, Prokopenko I, Farrall M, Dominiczak A; Diabetes Genetics Initiative; Wellcome Trust Case Control Consortium, Johnson T, Bergmann S, Beckmann JS, Vollenweider P, Waterworth DM, Mooser V, Palmer CN, Morris AD, Ouwehand WH; Cambridge GEM Consortium, Zhao JH, Li S, Loos RJ, Barroso I, Deloukas P, Sandhu MS, Wheeler E, Soranzo N, Inouye M, Wareham NJ, Caulfield M, Munroe PB, Hattersley AT, McCarthy MI, Frayling TM (2008) Genome-wide association analysis identifies 20 loci that influence adult height. Nat Genet. 40:575-583

Weedon MN, Lettre G, Freathy RM, Lindgren CM, Voight BF, Perry JR, Elliott KS, Hackett R, Guiducci C, Shields B, Zeggini E, Lango H, Lyssenko V, Timpson NJ, Burtt NP, Rayner NW, Saxena R, Ardlie K, Tobias JH, Ness AR, Ring SM, Palmer CN, Morris AD, Peltonen L, Salomaa V, The Diabetes Genetics Initiative, The Wellcome Trust Case Control Consortium, Smith GD, Groop LC, Hattersley AT, McCarthy MI, Hirschhorn JN, Frayling TM (2007) A common variant of HMGA2 is associated with adult and childhood height in the general population. Nat Genet 39:12451250

Willemsen G, Boomsma DI, Beem AL, Vink JM, Slagboom PE, Posthuma D (2004) QTLs for height: results of a full genome scan in Dutch sibling pairs. Eur J Hum Genet 12:820-828

Wiltshire S, Frayling TM, Hattersley AT, Hitman GA, Walker M, Levy JC, O'Rahilly S, Groves CJ, Menzel S, Cardon LR, McCarthy MI (2002) Evidence for linkage of stature to chromosome 3 p26 in a large U.K. Family data set ascertained for type 2 diabetes. Am J Hum Genet 70:543-546

Wu X, Cooper RS, Boerwinkle E, Turner ST, Hunt S, Myers R, Olshen RA, Curb D, Zhu X, Kan D, Luke A (2003) Combined analysis of genomewide scans for adult height: results from the NHLBI Family Blood Pressure Program. Eur J Hum Genet 11:271-274

Xu J, Bleecker ER, Jongepier H, Howard TD, Koppelman GH, Postma DS, Meyers DA (2002) Major recessive gene(s) with considerable residual polygenic effect regulating adult height: confirmation of genomewide scan results for chromosomes 6, 9, and 12 . Am J Hum Genet 71:646-650 